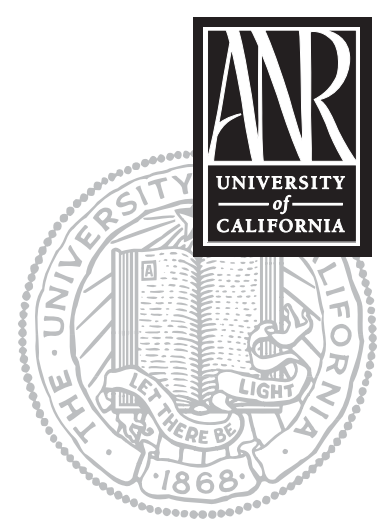

UNIVERSITY OF CALIFORNIA

Division of Agriculture and Natural Resources http://anrcatalog.ucdavis.edu

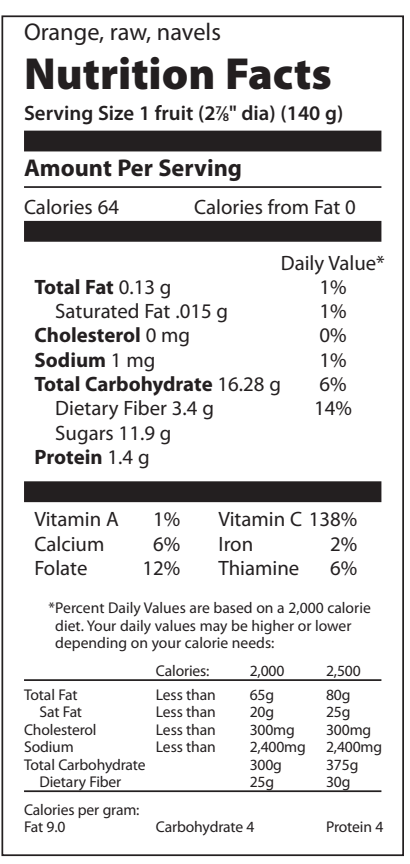

Figure 1. Nutrition facts for oranges.

\section{Oranges: Safe Methods to Store, Preserve, and Enjoy}

JENNIFER E. SNART, Postgraduate Researcher, Department of Food Science and Technology, UC Davis; MARY LU ARPAIA, Postharvest Extension Specialist, Department of Botany and Plant Sciences, UC Riverside; and LINDA J. HARRIS, Extension Specialist in Food Safety and Applied Microbiology, Department of Food Science and Technology, UC Davis.

\section{WHAT IS AN ORANGE?}

The sweet orange (Citrus sinensis) is a member of the citrus family, along with mandarins (tangerines), lemons, limes, grapefruit, and kumquats. In prehistoric times, the sweet orange was cultivated in several locations, including areas now occupied by modern China, India, Bhutan, Burma, and Malaysia. Citrus fruits followed trade routes west to Arabic countries, and later to northern Africa, Italy, and Spain. Europeans recognized the medicinal benefits of citrus, using the fruit to prevent scurvy on long sea voyages.

In 1493, Christopher Columbus brought orange and lemon seeds to North America. Ponce de Leon and his sailors planted citrus seed in Florida in 1513. Today, North America accounts for about $50 \%$ of the world's citrus production while Brazil is the world's leading producer of orange juice concentrate. The primary orangegrowing region in California is the southern part of the San Joaquin Valley. California produces oranges primarily for the fresh market while the majority of Florida oranges are grown for processing, mainly to juice. More than half of the fruit juice sold in the United States is orange juice. Orange products are marketed in many forms, including orange juice concentrate, fresh-squeezed juice, mixed fruit juices, smoothies (orange and yogurt mixtures), and marmalades. Orange oil, a non-food product, is used in surface conditioning of wood furniture and in mixtures with other citrus oils for hand cleansing and grease removal. Waste from juice and cut fruit processing is used as animal feed.

\section{NUTRITION}

Oranges and other citrus fruits are important sources of vitamin $C$ and folate (Figure 1). Oranges also provide significant amounts of antioxidants, such as betacarotene, and flavonoid compounds.

\section{GROWING ORANGES IN THE HOME GARDEN}

Orange varieties include Navel, Valencia, Hamlin, Pineapple, and Temple. The most commonly grown commercial varieties in California are Navel and Valencia (Figure 2). Navel oranges are generally seedless, though occasionally a seed may be found. Valencia oranges, however, can contain a few too many seeds. The number of seeds depends on many factors, including growing conditions, availability of honeybees, and nearness of other citrus trees.

Information on citrus varieties (including oranges) is available online through the University of California, Riverside, citrus variety collection homepage: http://citrusvariety.ucr.edu or http://ccpp.ucr.edu.

NOTE: Research on food preservation is ongoing — recommendations may change. Make sure your food preservation information is always current. Always follow up-to-date, tested guidelines and recipes from reliable sources. 1/2006 


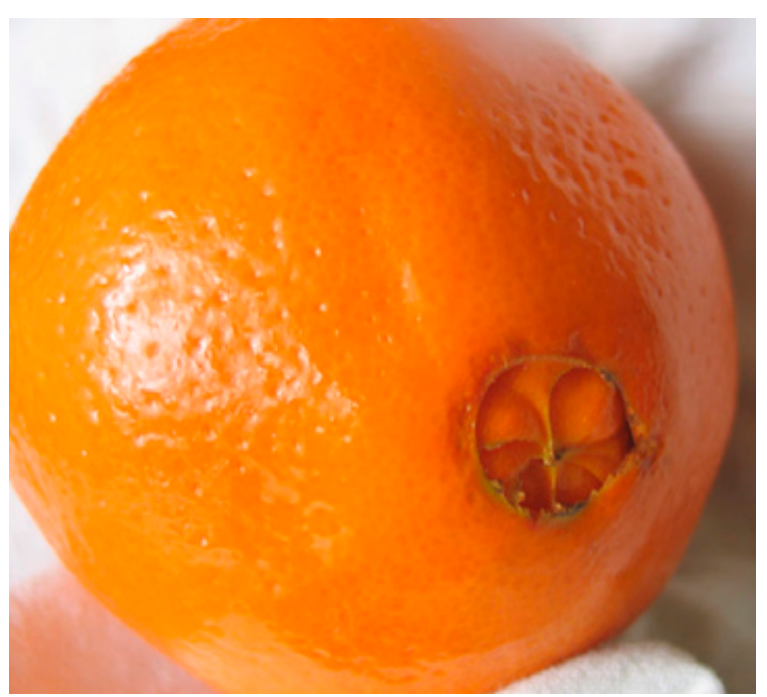

Figure 2. The "navel" end of a Navel orange.
Commercially grown citrus trees are grafted onto seedling rootstocks that have been selected for their disease tolerance under varying soil conditions and their influence on tree vigor, productivity, and fruit quality. Information on citrus pest and disease management is available online at http://www.ipm.ucdavis.edu/PMG/crops-agriculture.html.

A free online publication from the University of California, Key Points of Control and Management of Microbial Food Safety: Edible Landscape Plants and Home Garden Produce (UC ANR Publication 8101), provides information on ways to minimize contamination of fruits and vegetables in the home garden by organisms that can cause foodborne illness. You can access the publication at http://anrcatalog.ucdavis.edu.

Orange trees, like other citrus, tend to go through a "juvenile" phase for the first 2 to 3 years of fruit production. During this period, the tree may be more "thorny" and produce few fruit, but those fruit are generally large and coarse-peeled.

The trees typically bloom in the spring, with peak bloom occurring in April. A tree will produce many more flowers than it will set fruit. It will also shed many of its "fruitlets," or small underdeveloped fruit, in late May through June (known as the "June drop" period).

With Navel oranges, depending on the strain, the fruit will mature and be ready to harvest about 7 to 12 months after the fruit has set. Valencia oranges are slower to mature and generally are not ready to pick until 12 to 15 months after fruit set. A Valencia tree can carry two crops simultaneously-one mature and the other developing.

In the subtropical climate of California, an unusual color change may occur in mid to late autumn during the ripening of Navel oranges, and this can confuse home growers about the fruit's maturity. The peel color may change from green to orange when air and soil temperatures cool with the approaching winter. The color change can be misleading: it is not a true indicator of the fruit's level of maturity. Most Navel oranges mature in winter to early spring.

Valencia oranges mature in the late spring and typically remain on the tree during the summer months. The mature orange fruit will often undergo some "re-greening" of the skin. This process is natural, and is related to warmer air and soil conditions during summer.

Oranges grow in warm, subtropical climates, including Florida, California, and Texas in the United States. Optimal growing temperatures are $55^{\circ}$ to $64^{\circ} \mathrm{F}\left(13^{\circ}\right.$ to $\left.18^{\circ} \mathrm{C}\right)$ in winter, and up to $95^{\circ} \mathrm{F}\left(35^{\circ} \mathrm{C}\right)$ in summer.

\section{SELECTING ORANGES FROM THE HOME GARDEN}

Oranges and orange trees do not tolerate freezing temperatures well. Temperatures below $28^{\circ} \mathrm{F}$ $\left(-2^{\circ} \mathrm{C}\right)$ may result in twig or branch dieback as well as frozen fruit. Pick the oranges ahead of time if a freeze is expected.
Oranges do not ripen after they are harvested, so it is important to pick the fruit at the right stage of maturity. Orange maturity is related to several factors, including color, sugar content, acidity, and juice content. The orange should have a yellow-orange color on at least 25 percent of the peel. You can sample fruit periodically to check for maturity. The citrus industry will measure the sugar and acid levels of the fruit to determine its maturity-at home, tasting the fruit is the best way to determine whether it is ready to pick.

Harvest oranges from home garden trees by gently snapping or clipping the fruit

NOTE: Research on food preservation is ongoing — recommendations may change. Make sure your food preservation information is always current. Always follow up-to-date, tested guidelines and recipes from reliable sources. 1/2006 
CAUTION: Always store fresh fruits and vegetables away from raw meat products. from the stem. When fruit is snapped off the tree, the peel may tear at the stem. These fruit should be used first because, with a break in the peel, they are more likely to spoil. For longer-term storage of harvested oranges, take care to avoid cutting or scraping the peel. That kind of injury promotes more rapid spoilage of the fruit.

\section{SELECTING ORANGES AT THE GROCERY STORE}

Different types of Navel orange are harvested at different times so some oranges can normally be found in grocery stores from November through June. Valencia oranges mature later, and are generally available from March through September.

Choose oranges that are firm and heavy for their size, with fine-textured skin and no soft spots. Oranges should be free of cuts or bruises. Scars may develop on the peel where a young fruit has brushed against the tree, but these surface flaws do not affect the quality of the fruit inside.

\section{STORING FRESH ORANGES}

Commercial growers and handlers can store oranges for 3 to 8 weeks when refrigerated at $38^{\circ}$ to $48^{\circ} \mathrm{F}$ ( $3^{\circ}$ to $9^{\circ} \mathrm{C}$ ), depending on the initial condition of the fruit. Optimum humidity for storage of oranges is 90 to $95 \%$.

When growing oranges in the home garden, the best way for you to "store" oranges is to leave them on the tree during the typical harvest season. When this option is not practical, store the fruit in the crisper drawer of your refrigerator.

\section{SAFETY TIPS FOR HANDLING FRESH ORANGES}

\section{General Sanitation}

As of this writing, fresh oranges have not been associated with foodborne illness. However, Salmonella contamination has been associated with outbreaks of illness traced to drinking fresh (unpasteurized) orange juice and reconstituted frozen orange juice. The unpasteurized juices were likely contaminated through poor sanitation practices during juicing. Other sources of contamination for reconstituted juices have included the use of contaminated water when reconstituting the juice and the preparation of juice by an ill food handler with poor hygiene practices. We used to think that orange juice was too acidic to allow bacteria like Salmonella to survive, but we now know that bacteria can survive for long periods of time in orange juice and other fruit juices.

Like any other fresh fruit or vegetable, oranges can be contaminated by bacteria from soil, water, and animal sources. Contamination from human sources may occur during or after harvest, right up to the point of eating. Bacteria on the orange rind can be transferred to the internal flesh during cutting, peeling, or juicing. Food poisoning outbreaks with other types of produce have occurred when poorly washed utensils or cutting boards (especially those used to handle raw meats) have been used to prepare fruits or vegetables. For this reason, it is important that you wash your hands with soap and water before and after preparing produce and that you use clean equipment, utensils, and cutting surfaces.

\section{Washing Oranges}

Oranges should be washed before peeling or cutting. To wash, wet each orange with water, rub its surface, rinse it with running water, and dry it with a paper towel.

NOTE: Research on food preservation is ongoing - recommendations may change. Make sure your food preservation information is always current. Always follow up-to-date, tested guidelines and recipes from reliable sources. 1/2006 
CAUTION: Always cover and refrigerate cut or segmented oranges when preparing them in advance. Throw cut oranges away if they have been held for longer than 2 hours at room temperature or longer than 1 hour at temperatures over $90^{\circ} \mathrm{F}$ $\left(32^{\circ} \mathrm{C}\right)$.

NOTE: Navel oranges do not freeze well. A very bitter compound called limonin develops in oranges when they are frozen. This compound is found in higher levels in Navel oranges, which makes them a poor choice for freezing whole or as juice. If your Navel oranges have frozen on the tree, they may become bitter before picking. This bitterness will not go away over time. You may want to pick all of the oranges from a tree if a hard freeze is predicted.
Washing oranges in a sink filled with water is not recommended since the standing water can spread contamination from one orange to another. The use of soap or detergent is not recommended or approved for washing fruits and vegetables because the fruit can absorb detergent residues.

Cut or segmented oranges or products made from them, such as fruit salad, should be covered and refrigerated if they are not eaten within 2 hours of preparation. Cut or segmented oranges will last about 1 to 2 days if refrigerated.

\section{PRESERVING ORANGES}

Oranges are considered to be acidic, but their $\mathrm{pH}$ can vary significantly depending on their degree of maturity or ripeness as well as their variety. In general, the more ripe the orange, the higher (less acidic) is the $\mathrm{pH}$. The $\mathrm{pH}$ value of ripe oranges ranges from 3.6 to 4.3 .

\section{PRESERVATION METHODS: FREEZING ORANGES}

Wash the fruit as described in Washing Oranges, above. Peel the fruit before dividing it into sections. Remove membranes and seeds. Slice the oranges if desired.

Containers for freezing. Glass jars and rigid plastic containers make good freezer containers. Wide- and narrow-mouth canning and freezing jars are available. The glass in these jars has been tempered to withstand heat and cold. Glass jars not designed for freezing can easily break in the freezer. Most plastic bags made for freezing also work well. Ordinary waxed papers or paper cartons from milk do not work well because they do not keep air and moisture from moving in or out of the container.

Syrup pack. Pack orange pieces into containers. Cover fruit with cold, heavy syrup (40\% sugar, see Table 2 in Canning Oranges section) made with excess fruit juice or water. Keep the orange pieces submerged in the syrup by placing a small piece of crumpled waxed paper on top of the fruit in each container. Seal the container, leaving an appropriate headspace for expansion (Table 1), and freeze.

Unsweetened dry pack. Orange pieces can be packed tight without sugar and then frozen, but the result may be a product with less desirable flavor, texture, and color than if it had been packed with sugar.

Other unsweetened packs. In addition to dry pack, orange pieces can be packed in water, unsweetened juice, or pectin syrup. Unsweetened packs generally yield products that lack the plump texture and good color of fruit packed with sugar. The oranges freeze harder and take longer to thaw. Fruit packed in pectin syrup may retain its texture better than if frozen in water or juice.

Cover the orange pieces with water, juice, or pectin syrup (preparation of pectin

Table 1. Headspace needed between packed food and lid for freezing fruit

\begin{tabular}{|l|c|c|c|c|}
\hline \multirow{2}{*}{ Type of pack } & \multicolumn{2}{|c|}{ Container with wide-top opening } & \multicolumn{2}{c|}{ Container with narrow-top opening } \\
\cline { 2 - 5 } & Pint & Quart & Pint & Quart \\
\hline Liquid pack* & $1 / 2$ inch & 1 inch & $3 / 4$ inch & $1 \frac{1}{2}$ inches \\
\hline Dry pack & $1 / 2$ inch & $1 / 2$ inch & $1 / 2$ inch & $1 / 2$ inch \\
\hline
\end{tabular}

${ }^{*}$ Orange juice, or oranges packed in syrup, juice, or water.

tHeadspace for freezing orange juice should be $1 \frac{1}{2}$ inches.

‡Oranges packed without added sugar, sweeteners, or liquids.

NOTE: Research on food preservation is ongoing — recommendations may change. Make sure your food preservation information is always current. Always follow up-to-date, tested guidelines and recipes from reliable sources. 1/2006 
syrup is described below). Submerge the pieces by placing a small piece of crumpled waxed paper on top of them, as in Syrup pack, above. Seal the containers tight, leaving the correct headspace (Table 1), and freeze.

Pectin syrup. Combine 1 package powdered pectin with 1 cup $(250 \mathrm{ml})$ of water in a saucepan. Heat to boiling and maintain the boil for 1 minute. Remove from the heat and add 13/4 cup (435 ml) of water. Add more water if you want a thinner syrup. Cool. Yield is about 3 cups $(750 \mathrm{ml})$ of moderately thick syrup.

Using artificial sweeteners. Orange pieces can be packed in a sweet solution made by mixing water with sugar substitutes such as saccharin (e.g., Sweet'N Low), aspartame (e.g., Equal), or sucralose (Splenda). These artificial sweeteners work well in frozen products, or you can add them to the unsweetened, thawed fruit just before serving.

Artificial sweeteners give a sweet flavor but do not provide the beneficial preservation effects of sugar such as color protection, or thickness of syrup. The label on a sweetener package will tell you how much sweetener is equivalent to standard amounts of sugar. Use the label directions to determine the amount needed.

Freezing juice. Squeeze juice from oranges, using a juicer that does not press oil from the rind. Sweeten, if desired, using 2 tablespoons $(30 \mathrm{ml})$ of sugar for each quart of juice (30 ml sugar for $1 \mathrm{~L}$ juice) or substitute an appropriate equivalent amount of artificial sweetener, or pack the juice unsweetened. Pour the juice immediately into clean glass jars or rigid plastic freezer containers. Seal the jars or containers, leaving a 1 1/2-inch headspace (Table 1 ), and freeze.

\section{PRESERVATION METHODS: DRYING ORANGE PEEL}

Drying (dehydration) is the process of slowly removing water from food in order to preserve the food. Drying is not a recommended preservation method for oranges because they are too juicy and not very firm. However, orange peel and other types of citrus peel do dry well. The peel of a thick-skinned Navel orange dries better than that of a thinskinned Valencia.

Oven drying. It is possible to dry orange peel in your kitchen oven, but we do not recommend it since it takes so long: up to 24 hours to dry the peel adequately. The process heats up the kitchen, makes the oven unavailable for other uses, and is unsafe in homes with small children. If you wish to pursue oven drying, please consult other reliable references on the subject. One good online source is Preserving Food: Drying Fruits and Vegetables at http://www.fcs.uga.edu/pubs/PDF/FDNS-E-43-10.pdf.

Microwave drying. Do not attempt to use a microwave oven to dry orange peels. Peels require constant attention during drying, and the door would have to be opened frequently to allow moisture to escape. Microwave-dried orange peels do not dry evenly and they can easily scorch or burn.

Sun drying. Orange peel can be safely dried outdoors when conditions are right for drying (minimum temperature of $85^{\circ} \mathrm{F}\left[29^{\circ} \mathrm{C}\right.$ ] and humidity less than $60 \%$ ). Insects and birds are attracted to drying fruit rind, though, and they may contaminate it. If you wish to try sun drying, please consult other reliable references such as the Web site listed under Oven drying, above.

Dehydrator drying. Unlike sun drying, which depends on proper weather conditions, dehydrator drying can be done at any time. There is an initial expense involved in buying a dehydrator (Figure $3 \mathrm{a}$ and $\mathrm{b}$ ), but many people think that a dehydrator produces the best quality dried food. An electric dehydrator can maintain low, even temperatures, circulating the heated air by means of a blower or fan. Most dehydrators are

NOTE: Research on food preservation is ongoing — recommendations may change. Make sure your food preservation information is always current. Always follow up-to-date, tested guidelines and recipes from reliable sources. 1/2006 
equipped with thermostats to maintain a constant temperature, and some have timers. Larger units with many shelves have room for more food than most ovens.

Dehydrating orange peel. The oranges should be washed thoroughly, as described in Washing Oranges, above. Remove the outer peel (1/16 to $1 / 8$ inch) with a knife or vegetable peeler. Avoid including the white, bitter albedo (pith). No further pretreatment is required.

Set the dehydrator temperature at $130^{\circ}$ to $135^{\circ} \mathrm{F}\left(54^{\circ}\right.$ to $\left.57^{\circ} \mathrm{C}\right)$. If your dehydrator does not have a thermostat, place an accurate, easy-to-read thermometer on the bottom tray. Arrange the prepared orange peel pieces on the drying trays, cut-side-up and in a single layer. The pieces should not touch or overlap. Leave 1 to

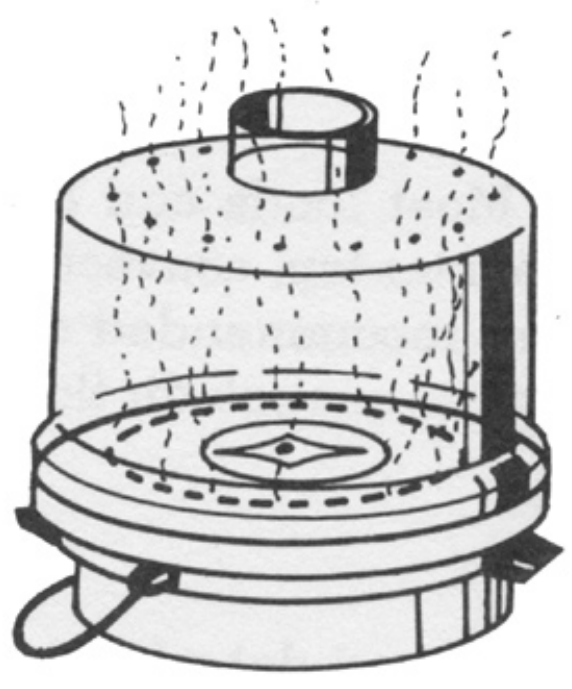

Figure 3 ( $a$ and b). Typical home dehydrators.

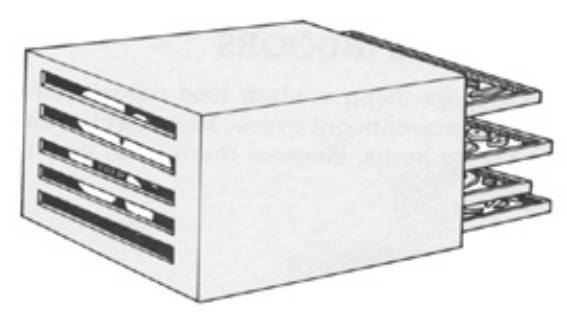
2 inches $(2.5$ to $5 \mathrm{~cm}$ ) between trays in the dehydrator. It may be necessary to rotate the racks' positions up and down the stack during the drying process. Continue dehydrating until the peel tests dry, as described below under Testing for dryness. Food dries much more quickly toward the end of the drying time, so watch closely and remove individual pieces as they dry.

The amount of time it takes to dry orange peel depends on its initial moisture content, the volume being dried, the size and thickness of the pieces, the air's humidity during the drying process, and the dehydrator's efficiency. A drying time of 8 to 12 hours in a food dehydrator is not uncommon.

Testing for dryness. To test for dryness, remove several pieces of peel from the dryer. After they have cooled, cut the pieces in half. There should be no visible moisture, and you should not be able to squeeze any moisture from the pieces. Some orange peel may remain pliable, but it should not be sticky or tacky. If you fold a piece in half, it should not stick to itself.

After drying, cool the pieces for 30 to 60 minutes before packaging. Avoid packaging warm peel, since that could lead to sweating and moisture buildup. You should also avoid long delays before you package it, though, because the orange peel may have an opportunity to reabsorb moisture from the air.

Conditioning dried orange peel. The water content of home-dried orange peel should be about $20 \%$. When you take the pieces from the dehydrator, the remaining moisture may not be distributed equally among pieces because of their size or where they were located in the dehydrator. Conditioning is the process used to make sure that all pieces are equally moist. This reduces the risk of mold growth.

To condition the orange peel, pack the dried, cooled pieces loosely in clean plastic or glass jars. Seal the containers and allow them to stand for 7 to 10 days. Excess moisture in some pieces will be absorbed by the drier pieces. Shake the jars daily to separate the orange peel, checking for any water condensation. If condensation (visible moisture buildup) appears in a jar, return the orange peel to the dehydrator for further drying. After conditioning, package and store the peel.

Packaging and storage. Dehydrated orange peel requires very little storage space. Completely dried orange peel can be stored in sealed plastic bags or airtight jars. Pack the orange peel tight in the bag or container, removing as much air as 
Wide- and narrow-mouth canning and freezing jars are available. The glass in these jars has been tempered to withstand heat and cold. Glass jars not designated for freezing and canning can easily break in the freezer or during canning.

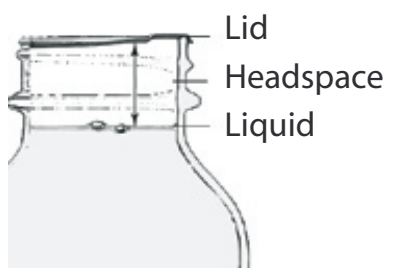

Figure 4. Leave adequate headspace in jars. possible. If you use metal containers, place the peel in a plastic bag first in order to prevent reaction with the metal. The dried peel should be stored in a dark, cool $\left(60^{\circ} \mathrm{F}\right.$ $\left[15^{\circ} \mathrm{C}\right]$ ) place. The peel's color, flavor, aroma, and nutritive value will start to decrease after about a year. For longer storage, you can keep well-wrapped orange peel in the freezer. For best flavor and quality, use within 2 years of frozen storage.

Check dried orange peel occasionally during storage to make sure the product is still dry. Glass containers are excellent for storage because any moisture that collects on the inside is easily seen. Orange peel that is affected by moisture but not spoiled should be used immediately or redried and repackaged. Moldy orange peel should be discarded.

Using dehydrated orange peel. Home-dried orange peel can be used in the same way as the commercial product. Try adding it as a flavoring in favorite recipes, such as breads and other baked items, fudge and other candies, gelatin, tossed and fruit salads, Asian dishes, stuffings, milkshakes, homemade ice cream, cooked cereals, and granola.

\section{PRESERVATION METHODS: CANNING ORANGES}

At pH 3.6 to 4.3, oranges are considered acidic. Foods high in acid are quite simple to preserve because the acid inhibits the growth of bacteria. The main spoilers of acidic foods are molds, yeasts, and enzymes, all of which are destroyed at the temperatures reached in a boiling water bath, the recommended treatment. Canned oranges taste better if the sections are packed with an equal quantity of grapefruit sections.

\section{Using the Right Equipment}

Containers for canning. Make sure all glass jars are free of cracks and chips. These defects will prevent airtight seals. Jars that are manufactured specifically for home canning are recommended. Glass mayonnaise jars and similar jars are not recommended for use in home canning because they are not manufactured for repeated heating and have a higher rate of breakage. Wash the jars in hot, soapy water and rinse them, or you can wash them in a dishwasher.

Lids and rings. Select the correct size of lids to fit your jars. Always use new lids each time you do canning. Rings can be reused if they are in good condition. Wash and thoroughly dry the rings before you store them and they will remain in good condition for years. Follow the manufacturer's instructions for pretreating the canning lids. Metal lids have a sealing compound and usually need to be heated prior to use.

Filling jars. Do not overfill the jars. Pack the citrus slices or marmalade to the shoulder of the jar, leaving room for the covering liquid (if used) and recommended headspace (Figure 4). After adding liquid to the recommended headspace, use a plastic knife or spatula to dislodge air bubbles trapped on the inner side of the jars. Then add more liquid if necessary.

Adjusting seals. With a clean, damp cloth or towel, carefully wipe the rim and screw threads of the jar. Place the clean, prepared lid on the rim of the jar and screw the ring band on firmly. Do not overtighten. If tightened too much, the lids will not vent correctly, causing buckling of the lid, loss of the seal a day or two after processing, and possibly glass breakage during processing.

\section{Using a Water Bath Canner}

Any large covered kettle or pot may be used as a water bath canner (Figure 5), if it is

NOTE: Research on food preservation is ongoing — recommendations may change. Make sure your food preservation information is always current. Always follow up-to-date, tested guidelines and recipes from reliable sources. 1/2006 


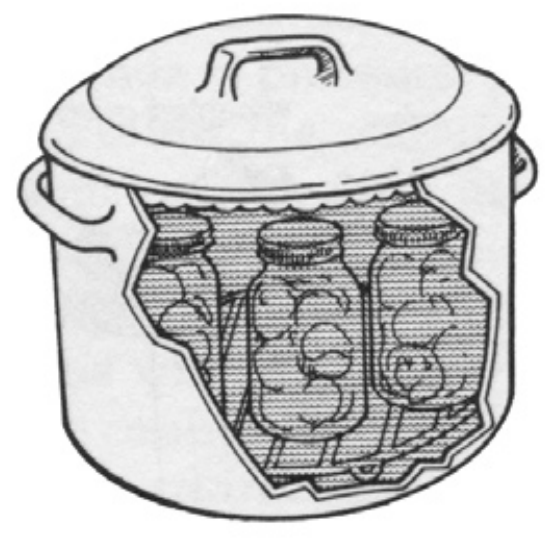

Figure 5. Water bath canner. deep enough to allow water to cover the tops of the jars by 1 to 2 inches (Figure 6). Fill the canner half full with water. Preheat the water to $140^{\circ} \mathrm{F}\left(60^{\circ} \mathrm{C}\right)$. Jars should be placed on a rack in the canner; any jars that come into direct contact with the bottom of the canner may break. Add enough boiling water to cover the tops of the jars by at least $1 \mathrm{inch}$. When water comes to a boil, begin to count the processing time indicated in the recipe. At the end of the recommended processing time, remove jars from the canner and cool them, undisturbed, at room temperature. Avoid placing jars directly on cold surfaces like tile countertops as that may cause the jars to crack. Setting the jars on a towel over the countertop rather than directly on the countertop can help protect jars from breaking. After the jars have cooled, check them for a tight seal. Remove the rings and wash the jars gently before storage to remove any syrup residues. Store in a dark, dry, cool place.

\section{Using a Water Bath Canner at Higher Altitudes}

The processing times given in the recipe are for elevations of 0 to 1000 feet. At higher altitudes, you must increase the processing time as recommended for that recipe.

\section{Canning Oranges and Grapefruits: Raw Pack}

Choose oranges and grapefruit that are firm, sweet, and eating-ripe. Oranges in this combination may be canned in water, citrus juice, or sweet syrup. The sugar in the syrup or juice will help the fruit pieces hold their shape, color, and flavor, but sugar is not necessary to prevent spoilage. If you use syrup, make it before you prepare the fruit. Make a very light, light, or medium syrup using the proportions given in Table 2. Bring the water, juice, or syrup to a boil and keep it hot.

Wash the fruit as described in Washing Oranges, above. Peel the fruit and remove the white tissue (albedo) to prevent development of any bitter taste. Separate the fruit into sections, removing membranes and seeds. Fill hot, clean jars with fruit sections and add hot water, juice, or syrup, leaving a $1 / 2$-inch headspace. Remove air bubbles using a plastic knife or spatula. Wipe the jar rims and adjust the lids. Process in a boiling water bath for the time indicated in Table 3.

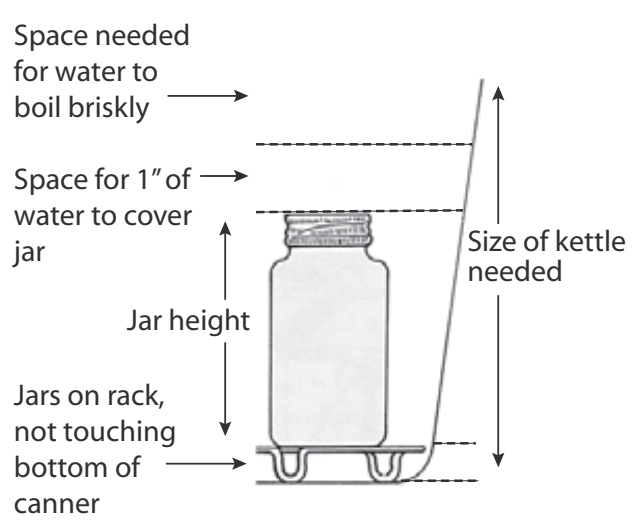

Figure 6. Space needed for adequate water coverage.
Table 2. Syrups for freezing or canning oranges and grapefruit

\begin{tabular}{|l|c|c|c|c|}
\hline Syrup type & $\begin{array}{c}\text { Percentage } \\
\text { sugar* }\end{array}$ & Sugar & Water & $\begin{array}{c}\text { Syrup yield } \\
\text { in cups }(\mathrm{ml})\end{array}$ \\
\hline Very light & $10 \%$ & $\begin{array}{c}1 / 2 \text { cup } \\
(125 \mathrm{ml})\end{array}$ & $\begin{array}{c}4 \text { cups } \\
(1 \mathrm{~L})\end{array}$ & $\begin{array}{c}4 \frac{1}{2} \text { cups } \\
(1,125 \mathrm{ml})\end{array}$ \\
\hline Light & $20 \%$ & $\begin{array}{c}1 \text { cup } \\
(250 \mathrm{ml})\end{array}$ & $\begin{array}{c}4 \mathrm{cups} \\
(1 \mathrm{~L})\end{array}$ & $\begin{array}{c}4 / 4 \mathrm{cups} \\
(1,175 \mathrm{ml})\end{array}$ \\
\hline Medium & $30 \%$ & $\begin{array}{c}13 / 4 \mathrm{cups} \\
(425 \mathrm{ml})\end{array}$ & $\begin{array}{c}4 \text { cups } \\
(1 \mathrm{~L})\end{array}$ & $\begin{array}{c}5 \mathrm{cups} \\
(1,250 \mathrm{ml})\end{array}$ \\
\hline Heavy & $40 \%$ & $\begin{array}{c}23 / 4 \text { cups } \\
(675 \mathrm{ml})\end{array}$ & $\begin{array}{c}4 \text { cups } \\
(1 \mathrm{~L})\end{array}$ & $\begin{array}{c}51 / 3 \mathrm{cups} \\
(1,325 \mathrm{ml})\end{array}$ \\
\hline
\end{tabular}

To make syrup, add the sugar to the water and stir, heating as necessary to dissolve.

*Approximate amount. In general, up to one-half of the sugar may be replaced by corn syrup or mildflavored honey. A larger proportion of corn syrup may be used if it is a very bland, light-colored type. 
Table 3. Recommended processing times for orange and grapefruit sections in boiling water bath at various altitudes

\begin{tabular}{|l|l|l|l|l|}
\hline Style of pack & Jar size & $\begin{array}{l}\text { Processing time at } \\
0-1000 \mathrm{ft} \text { elevation }\end{array}$ & $\begin{array}{l}\text { Processing time at } \\
1001-6000 \mathrm{ft} \text { elevation }\end{array}$ & $\begin{array}{l}\text { Processing time above } \\
6000 \mathrm{ft} \text { elevation }\end{array}$ \\
\hline Raw & Pint or quart & 10 minutes & 15 minutes & 20 minutes \\
\hline
\end{tabular}

\section{JAMS AND JELLIES}

Oranges do not make very good jams and jellies, but are excellent in marmalades.

\section{CITRUS MARMALADE}

Makes 6 half-pint $(250 \mathrm{ml})$ jars

Ingredients

4
2
$2 \frac{1}{2}$ cups
$1 / 8$ teaspoon
$61 / 2$ cups
1 package
$1 / 4$ teaspoon

oranges (medium)

lemons (medium)

water

baking soda

sugar

powdered pectin

butter or margarine

4
2
$625 \mathrm{ml}$
$1 / 2 \mathrm{ml}$
$1.625 \mathrm{~L}$
1 package
$1 \mathrm{ml}$

4

2

$\mathrm{ml}$

age

$\mathrm{ml}$

\section{Preparation}

1. Wash your hands, utensils, and work surfaces, and then prepare the ingredients.

2. Sterilize empty canning jars by placing them upright on rack in water bath canner and covering them with hot water to 1 inch above the tops of the jars. Boil 10 minutes. At altitudes higher than $1000 \mathrm{ft}$, boil the jars an additional 1 minute for each additional $1000 \mathrm{ft}$ elevation. Keep the jars hot and drain just prior to filling. For more detailed information on waterbath canning, refer to the Canning Oranges section.

3. Wash the oranges and lemons. Remove the rind in quarters from oranges and lemons. Trim and discard half of the albedo (white flesh attached to the rind).

4. Thinly slice the rinds and place in a 4-quart $(4 \mathrm{~L})$ saucepan.

5. Mix the rinds with water and baking soda. Bring to a boil, reduce heat, cover, and simmer for 20 minutes, stirring occasionally.

6. While the rinds are cooking, remove seeds from the peeled oranges and lemons, and finely chop the fruit, saving the juice. Set aside.

7. Add reserved fruit and juice to the cooked rind mixture. Cover, bring to a boil, reduce heat, and simmer 10 minutes.

8. Measure exactly 4 cups of cooked fruit and rind mixture (a box of pectin is sufficient to gel this much liquid). Use a slotted spoon to make sure you get all of the fruit and rind, and then use the juice to bring the total vol- ume up to 4 cups. Discard any leftover juice or use it in another recipe that calls for orange juice.

9. Add pectin and butter or margarine to the measured fruit. The butter or margarine reduces foaming during the cooking process.

10. Bring the mixture to a vigorous boil that cannot be stirred down, stirring constantly. Boil for 1 minute.

11. Add sugar to the mixture. Return to a boil that cannot be stirred down, stirring constantly. Boil for 1 minute.

12. Remove from heat and let stand 5 minutes, stirring occasionally.

13. Prepare two-piece canning lids according to manufacturer's recommendations.

14. Ladle hot marmalade into hot, sterile jars, leaving 1/4 inch of headspace.

15. Wipe the jars and the rim with a clean cloth or towel, place a clean prepared lid on the rim, and screw the ring band on finger-tight.

16. Process in a boiling waterbath canner for 5 minutes (altitudes of up to $1000 \mathrm{ft}$ ). (Increase processing time by 1 minute for every additional $1000 \mathrm{ft}$ in altitude.)

17. Let jars cool undisturbed for 12 to 24 hours, then check seals by pressing the middle of the lid with your finger. If the lid springs back, then the jar is not sealed and must be refrigerated. Properly sealed jars can be stored in a dark, cool place. 


\section{ADDITIONAL RESOURCES}

UC Food Safety at UC Davis provides information about food safety and has links to resources on home food preservation.

http://ucfoodsafety.ucdavis.edu

The National Center for Home Food Preservation provides science-based information on home food preservation for Extension educators, other educators, and home food preservers. http://www.uga.edu/nchfp

The University of Georgia College of Family and Consumer Sciences, Food Safety and Preservation Section provides extensive publications on canning/ preservation, food safety, and other food-related information. http://www.fcs.uga.edu/ext/pubs/index.php

AboutProduce.com is a Web page maintained by the Produce Marketing Association. It has extensive information about produce, including recipes and nutritional information. http://www.aboutproduce.com

The Fruit and Nut Research and Information Center has information on growing fruits and tree nuts in the home garden. http://fruitsandnuts.ucdavis.edu

The Postharvest Technology Research and Information Center at UC Davis provides information on storing fresh fruits and vegetables. http://postharvest.ucdavis.edu

\section{ACKN OWLEDGMENTS}

The University of California's Division of Agriculture and Natural Resources provided support for the development and production of this publication. FDA CFSAN grant number 001629-01-1 and USDA CSREES grant number 00-52102-9637 provided funding for research related to washing oranges. A special thanks to Sylvia Yada, Donna Gaboury, and Judy Howard for editorial and design assistance. Diagrams have been used or adapted with permission from the 1999 edition of So Easy to Preserve by Elizabeth L. Andress and Judy A. Harrison (Bulletin 989, 4th ed., Cooperative Extension Service, The University of Georgia, Athens).

\section{FOR MORE INFORMATION}

You'll find related information in these titles and in other publications, slide sets, CD-ROMs, and videos from UC ANR:

Cantaloupe: Safe Methods to Store, Preserve, and Enjoy, Publication 8095

Safe Handling of Fruits and Vegetables, Publication 8121

Tomatoes: Safe Methods to Store, Preserve, and Enjoy, Publication 8116

To order these products, visit our online catalog at http://anrcatalog.ucdavis.edu. You can also place orders by mail, phone, or FAX, or request a printed catalog of publications, slide sets, CDROMs, and videos from

University of California

Agriculture and Natural Resources

Communication Services

6701 San Pablo Avenue, 2nd Floor

Oakland, California 94608-1239

Telephone: (800) 994-8849 or (510) 642-2431

FAX: (510) 643-5470

E-mail inquiries: danrcs@ucdavis.edu 


\section{UC}

An electronic version of this publication is available on the ANR Communication Services Web site at http://anrcatalog.ucdavis.edu.

Publication 8199

(C)2006 by the Regents of the University of California Division of Agriculture and Natural Resources.

All rights reserved.

The University of California prohibits discrimination or harassment of any person on the basis of race, color, national origin, religion, sex, gender identity, pregnancy (including childbirth, and medical conditions related to pregnancy or childbirth), physical or mental disability, medical condition (cancer-related or genetic characteristics), ancestry, marital status, age, sexual orientation, citizenship, or status as a covered veteran (covered veterans are special disabled veterans, recently separated veterans, Vietnam era veterans, or any other veterans who served on active duty during a war or in a campaign or expedition for which a campaign badge has been authorized) in any of its programs or activities.

University policy is intended to be consistent with the provisions of applicable State and Federal laws.

Inquiries regarding the University's nondiscrimination policies may be directed to the Affirmative Action/Staff Personnel Services Director, University of California, Agriculture and Natural Resources, 300 Lakeside Drive, 6 $6^{\text {th }}$ Floor, Oakland, CA 94612-3550, (510) 987-0096. For information about obtaining this publication, call (800) 994-8849. For downloading information, call (530) 297-4445.

To simplify information, trade names of products have been used. No endorsement of named products is intended, nor is criticism implied of similar products that are not mentioned.

This publication has been anonymously peer reviewed for technical accuracy by University of California scientists and other qualified professionals. This review process was managed by the ANR Associate Editor for Food and Nutrition.

pr-5/06-WJC/CR 
Contents

Figure 1. Nutrition facts for oranges.

WHAT IS AN ORANGE?

JAMS AND JELLIES

\section{NUTRITION}

ADDITIONAL RESOURCES

\section{GROWING ORANGES IN THE HOME GARDEN}

ACKNOWLEDGMENTS

Figure 2. The "navel" end of a Navel orange.

FOR MORE INFORMATION

\section{SELECTING ORANGES FROM THE HOME \\ GARDEN}

\section{SELECTING ORANGES AT THE GROCERY}

STORE

STORING FRESH ORANGES

\section{SAFETY TIPS FOR HANDLING FRESH \\ ORANGES}

General Sanitation

Washing Oranges

Table 1. Headspace needed between packed food and lid for freezing fruit

\section{PRESERVING ORANGES}

\section{PRESERVATION METHODS: FREEZING \\ ORANGES}

\section{PRESERVATION METHODS: DRYING ORANGE PEEL}

Figure 3 (a and b). Typical home dehydrators.

Figure 4. Leave adequate headspace in jars.

\section{PRESERVATION METHODS: CANNING ORANGES}

\section{Using the Right Equipment}

Using a Water Bath Canner

Figure 5. Water bath canner.

Figure 6. Space needed for adequate water coverage.

Using a Water Bath Canner at Higher Altitudes

Canning Oranges and Grapefruits: Raw Pack

Table 2. Syrups for freezing or canning oranges and grapefruit

\section{CITRUS MARMALADE}

Table 3. Recommended processing times for orange and grapefruit sections in boiling water bath at various altitudes 